\title{
Influence of Integration of ICT on Human Resource Management in Kenyan Public Universities
}

\author{
Daniel Karanja, Anthony Kiplang'at Sang, Mwangi Ndirangu \\ Department of Curriculum, Instruction \& Educational Management, Egerton University, Njoro, Kenya \\ Email address: \\ dkaranke@gmail.com (D. Karanja), sangatoney@live.com (A. K. Sang), mndirangu@egerton.ac.ke (M. Ndirangu)
}

\section{To cite this article:}

Daniel Karanja, Anthony Kiplang'at Sang, Mwangi Ndirangu. Influence of Integration of ICT on Human Resource Management in Kenyan Public Universities. International Journal of Sustainability Management and Information Technologies. Vol. 3, No. 6, 2017 , pp. 73-78. doi: 10.11648/j.ijsmit.20170306.13

Received: November 16, 2017; Accepted: December 8, 2017; Published: January 11, 2018

\begin{abstract}
ICT is currently permeating every aspect of human life. In higher education, ICT is being seen as a crucial tool that facilitates acquisition, use and management of information that is critical in decision-making. Despite the many efforts and initiatives that have been put into place by the Kenya government, the private sector and the institutions themselves to leverage the use of ICT in public universities, little is known on how this integration has enhanced the provision of effective and efficient institutional management services. The purpose of this study was to investigate the influence of integration of ICT on human resource management in public universities in Kenya. The study adopted a descriptive survey research design. The target population comprised of all the lecturers and senior administrators in public universities in Kenya. The three oldest public universities in the country namely: University of Nairobi, Moi and Kenyatta Universities were purposively sampled to participate in the study. All the registrars' administration took part in the study. The determination of sample size for the lecturers was done using the Cochran's (1977) formula. Proportionate random sampling was used to obtain samples as follows: 167 lecturers from the University of Nairobi; 77 from Moi and 100 from Kenyatta. Data were analyzed using the Statistical Package for Social Sciences (SPSS) version 22 computer programme. The study established that though ICT integration was perceived by lecturers to have a positive influence on HRM, the influence was markedly on HR administrative functions such as employee's record management and payroll administration. It was however minimal on the more strategic applications such as staff recruitment and selection, training and development as well as performance management.
\end{abstract}

Keywords: ICT, Integration of ICT, Human Resource Management

\section{Introduction}

Information and communication technologies (ICTs) have revolutionized management of Higher educational institutions (HEIs) bringing forth new ways of doing things innovatively, efficiently and more effectively. [1] notes that quick and accurate decisions by HEIs managers require readily available and relevant information, a fact that makes ICT a vital tool in today's HEIs business world.

On the side of human resource management (HRM), [2] notes that ICT integrated systems like the Human Resource Information System (HRIS) enable HEIs to format a profile of their staff -their strengths and weaknesses- so as to know what they have in the human resource sense. Accordingly, they are able to structure appropriate development, promotion, training and recruitment hence ensuring that institutions have the right personnel in all its sectors at the right time and in the right numbers. [2] also argues that nowadays higher education institutions face a significant challenge of improving learning environments at reduced administrative operating cost. Moreover, the ability to effectively budget for and manage different types of employees, recruit and retain skilled staff requires full integration of HR data with student information systems. Therefore, with so many demands, higher learning institutions need powerful ICT solutions that would help them manage student academic, human resource and financial data.

The most common benefits of HRIS include improved accuracy of information, its timely and quick provision, as well as saving of costs [3]. Likewise, [4] stated five reasons that justify why organizations should use HRIS as: increasing 
competitiveness by developing and enhancing HR procedures and activities; generating a greater range of HRM reports necessary for decision making; shifting the role of HRM from transactional to strategic human resource management (SHRM)- a more favourable approach to managing human resources that supports long-term business goals and outcomes with strategic framework; and reengineering HRM departments in organizations.

Significant efforts to place ICT in the service of institutional management are notable in Kenya. For instance, the country drafted an ICT policy in January 2006. The policy objective sought to encourage the use of Information Technology in schools, colleges, universities and other educational institutions in the country so as to enhance their institutional management as well as improve the quality of teaching and learning [5]. In addition, Kenya's Ministry of Education (MoE) articulated the role of ICT in education in documents such as Kenya Education Sector Support Program (KESSP). The KESSP provided a roadmap for investment in ICT in education and suggested provisional budgets to support educational activities. The proposed investment programme on institutional management systems for instance was intended to achieve efficiency and effectiveness on management of institutional data, decision-making and administration as well as planning [6].

In terms of ICT initiatives, the government as well as most of the Kenyan universities have invested heavily in ICT projects. [7] observe this by noting that key projects include the Kenya Education Network (KENET) Bandwidth Expansion Project at a cost of US\$ 12 million and the East African Marine Cable System at a cost of about Ksh. 6 billion. These authors add that universities are buying computers, increasing bandwidth and connectivity, as well as enhancing their other infrastructure to harness the potential of ICT use in education activities.

Despite all these, it has not been clear how the heavy investment in ICTs has benefited public universities in their management processes. It is in this context that this study sought to fill this gap in knowledge by investigating the influence of integration of ICT on human resource management in Kenyan public universities.

\subsection{Objective of the Study}

The following was the research objective:

To determine the influence of integration of ICT on human resource management in public universities in Kenya.

\subsection{Research Hypotheses}

The study addressed the following research hypothesis:

$\mathrm{H}_{0}$ There is no statistically significant influence of integration of ICT on human resource management in public universities in Kenya.

\section{Methodology}

This study adopted a descriptive survey research design.
The target population comprised of all the lecturers and senior administrators in public universities in Kenya totaling to 5211. The three oldest public universities in the country namely: University of Nairobi, Moi and Kenyatta Universities were purposively sampled to participate in the study. All the registrars' administration participated. The determination of sample size for the lecturers was done using the [8] formula. In Cochran's formula, the alpha level is incorporated into the formula by utilizing the t-value for the alpha level selected (e.g. t-value for alpha level of 0.05 is 1.96 for sample size above 120). For categorical data, 5\% margin of error is acceptable [9]. Cochran's sample size formula for categorical data is:

$$
\begin{aligned}
& n=\frac{(t)^{2}(p)(q)}{(d)^{2}}=384 \\
& n=\frac{(1.96)^{2}(.5)(.5)}{(.5)^{2}}=384
\end{aligned}
$$

$\mathrm{n}=$ the desired sample size

$\mathrm{t}=$ value of selected alpha level of.025 in each tail $=1.96$ (the alpha level of.05 indicates

the level of risk the researcher is willing to take, true margin of error may exceed the margin of acceptable margin of error.

(p) $(q)=$ estimate of variance $=.25$ (Maximum possible proportion $(.5)^{*}$ 1-maximum possible proportion (.5) produces maximum possible sample size)

$\mathrm{d}=$ acceptable margin of error for proportion being estimated $=.05$ (Error researcher is willing to accept)

Thus, for a population of 3,307 lecturers, the required sample is calculated as follows:

$$
\begin{aligned}
& \mathrm{n}=\frac{n}{(1+n / \text { population })}=384 \\
& \mathrm{n}=\frac{384}{1+384 / 3,307}=344
\end{aligned}
$$

Proportionate random sampling was used to obtain samples as follows: 167 lecturers from the University of Nairobi; 77 from Moi and 100 from Kenyatta. Instruments' validity was determined by expert judgment. Based on data from a pilot study, a Cronbach alpha coefficient of 0.73 was obtained for lecturers' questionnaire and 0.80 for registrars' administration. Data were analyzed using the Statistical Package for Social Sciences (SPSS) version 22 computer programme. All tests of significance were done at a confidence level of $95 \%$.

\section{Results and Discussion}

This study sought to determine the influence of ICT integration on human resource management in public universities in Kenya. The objective was measured at two levels: The levels of perceptions by lecturers and registrars administration respectively. The findings on the perceptions of lecturers were as indicated in subsection 3.1. 


\subsection{Lecturers' Perceptions on the Influence of ICT Integration in HRM}

Lecturers were requested to indicate on a 5 point likert scale, their perceptions on items designed to measure the influence of ICT integration on human resource management in their institutions. Their responses were as indicated on Table 1:

Table 1. Lecturers Perceptions on Influence of ICT Integration in Human Resource Management.

\begin{tabular}{|c|c|c|c|c|c|c|}
\hline \multirow[t]{2}{*}{ Function } & \multicolumn{6}{|c|}{ Responses (\%) } \\
\hline & $\mathbf{N}$ & SD & D & $\mathbf{U}$ & $\mathbf{A}$ & SA \\
\hline Enables online staff recruitment processes & 243 & 4.5 & 29.8 & 13.6 & 37.7 & 14.4 \\
\hline Captures information on staff profiles & 243 & 4.5 & 14.1 & 13.6 & 36.7 & 15.4 \\
\hline Enables easy accessing of employee's information when needed & 243 & 9.5 & 4.9 & 9.9 & 60.1 & 15.6 \\
\hline Enables HR department to collect and assess employees' work information & 243 & 9.1 & 13.3 & 23.0 & 46.4 & 8.2 \\
\hline Supports payroll administration as well as pension and benefits management & 243 & 1.6 & 4.1 & 14.0 & 60.9 & 19.3 \\
\hline Enables employees to view their pay slips online & 243 & 8.6 & 14.0 & 3.3 & 36.6 & 37.4 \\
\hline Enables employees to apply for leave online & 243 & 18.5 & 19.3 & 11.1 & 39.9 & 11.1 \\
\hline Enables employees to query and receive HRM related information via SMSs on their mobile phones & 243 & 14.0 & 15.2 & 14.8 & 39.9 & 16.0 \\
\hline
\end{tabular}

Source: Field data.

Results on Table 1 show that integration of ICT in the universities' human resource management had enhanced easy access to employee's information (75.7\%), payroll administration (81.2\%) as well as online pay slips (74.0\%). These are mainly administrative functions. [10] in a study to assess the uses of HRIS in companies in Canada and Hong Kong, described applications of HRIS in functions such as employee record-keeping, payroll and payroll benefits administration as 'unsophisticated' uses of HRIS. [10] noted that the subsequent effects of these applications help HRIS to achieve basic purposes of cost and time reduction, process automation and efficiency gains in an organization. According to [10] sophisticated uses of HRIS that include support for employees recruitment and performance management aid in achieving an organization's long term strategic objectives.

Table 1 also indicates that ICT integration had a somewhat average influence on the following processes: Staff recruitment management $(52.1 \%)$, staff profiles management $(52.1 \%)$, work information management $(54.6 \%)$, leave application management $(51 \%)$ as well as use of SMS to query and receive HRM information (55.9\%). It was also evident that the least application of ICT in the universities HRM was on monitoring employees work attendance (29.6\%). These average and low applications of ICTs in the management of human resource imply that the universities were not in a position to reap the full benefits associated with ICT integration in HRM.

To determine the influence of integration of ICT on human resource management, a simple linear regression analysis was conducted. The regression analysis model summary showing the correlation coefficient (R) and the coefficient of determination ( $\mathrm{R}$ square) is as presented on Table 2:

Table 2. SPSS Output for Regression Analysis Showing Model Summary.

\begin{tabular}{lllll}
\hline Model & R & R Square & Adjusted R Square & $\begin{array}{l}\text { Std. Error of } \\
\text { the Estimate }\end{array}$ \\
\hline 1 & $.498^{\mathrm{a}}$ & .248 & .245 & .74992 \\
\hline
\end{tabular}

a. Predictors: (Constant), ICT integration.

The correlation coefficient of model summary was 0.498 as indicated on Table 2. This illustrates that there was a positive correlation between ICT integration and human resource management. The coefficient of determination (R square) was 0.248 indicating that the independent variable (ICT integration) accounted for $24.8 \%$ of the cause of variation in the dependent variable (human resource management).

The reliability of the regression model was checked by undertaking ANOVA. This was because the data under consideration was likert scale items utilizing a similar scale measurement [11]. The regression analysis showing ANOVA is as indicated on Table 3:

Table 3. SPSS Output for Regression Analysis Showing ANOVA ${ }^{a}$.

\begin{tabular}{llllll}
\hline Model & & Sum of Squares & df & Mean Square & F \\
\hline \multirow{2}{*}{1} & Regression & 44.670 & 1 & 44.670 & 79.430 \\
& Residual & 135.534 & 241 & .562 & \\
& Total & 180.205 & 242 & & \\
\hline
\end{tabular}

a. Dependent Variable: Human resource management.

b. Predictors: (Constant), ICT integration.

The $p$ value or level of significance of.000 indicated on Table 3 illustrates that the available data was good fit for model [11]. This implies that there was strong evidence that the regression model gave accurate predictions on the relationship between ICT integration and human resource management.

To determine the predictive effect of the independent variable (ICT integration) on the dependent variable (human resource management), the regression coefficients were used as indicated on Table 4: 
Table 4. SPSS Output for Regression Analysis Showing Coefficients ${ }^{a}$.

\begin{tabular}{lllllll}
\hline \multirow{2}{*}{ Model } & & \multicolumn{2}{c}{ Unstandardized Coefficients } & \multicolumn{2}{l}{ Standardized Coefficients } & \multirow{2}{*}{ t } \\
\cline { 3 - 6 } & & B & Std. Error & Beta & 10.853 \\
\multirow{2}{*}{1} & (Constant) & 1.969 & .181 & .000 & .000 \\
& ICT integration & .477 & .053 & .498 & 8.912 & .000 \\
\hline
\end{tabular}

a. Dependent Variable: Human resource management.

The regression coefficients illustrated on Table 4 showed a constant of 1.969 and a regression coefficient of 0.477 in respect to ICT integration. This is represented by the equation:

$y=1.969+0.477 x_{1} ;$ where

$\mathrm{y}=$ Human resource management

$\mathrm{x}_{1}=\mathrm{ICT}$ integration

This regression model indicates that a unit increase in ICT integration will lead to a 0.477 increase in human resource management. There is thus a positive influence of ICT integration on human resource management as illustrated by regression coefficient of 0.477 . The hypothesis stated below was tested using the $t$ statistics shown on Table 4.

$\mathrm{H}_{0}$ : There is no statistically significant influence of integration of ICT on human resource management as perceived by lecturers.

The hypothesis was tested at.05 level of significance with a rule to reject $\mathrm{H}_{0}$ if the $\mathrm{p}$ value $\leq .05$. The $\mathrm{p}$ value for this study was.000 which was below.05 hence leading to a conclusion to reject $\mathrm{H}_{0}$ and accept $\mathrm{H}_{\mathrm{a}}$. This implies that there was a statistically significant influence of integration of ICT on human resource management in Kenyan public universities as perceived by the lecturers.

[12] argues that integration of ICT in human resource management (HRM) provide it with the opportunity to become a more efficient and strategic function by standardizing the majority of the organization's HR processes, improving the quality and speed of available information and improving services to employees. [13] also argue that HRISs play a strategic architectural role as they contribute to overall business performance of organizations by fulfilling or at least supporting the tasks of data storage and retrieval, while at the same time serving as primary administrative support tools of reporting and statistics as well as of program monitoring. These authors further argue that HRIS helps to decrease costs by automating information and decreasing the number of HR employees needed. This information automation enables employees to control their own personal information while managers get to access relevant information and data, conduct analyses, make decisions and communicate with others without relying on services of HR professionals. [14] in a study to investigate the influence of HRIS on performance of Kenyan public universities found that HRIS application on recruitment and selection, training and development, payroll and performance management cumulatively provided quality, accurate and consistent data that enabled effective and efficient decision making among the institutions. The study's results further showed that HRIS reduced institutional operational costs as it enhanced maintenance of data with more accuracy and in less time.

\subsection{Administrators Perceptions on Influence of ICT Integration on HRM}

Registrars in charge of administration in respective universities were also requested to indicate using the same 5 point likert scale, their perceptions on items designed to measure the influence of ICT integration on human resource management in their institutions. Their responses were as indicated on Table 5:

Table 5. Registrars (Administration) Perceptions on Influence of ICT Integration in HRM.

\begin{tabular}{|c|c|c|c|c|c|c|}
\hline \multirow{2}{*}{ Function } & \multicolumn{6}{|c|}{ Responses (\%) } \\
\hline & $\mathbf{N}$ & SD & D & $\mathbf{U}$ & $\mathbf{A}$ & SA \\
\hline Enables online staff recruitment processes & 3 & 0 & 33.3 & 0 & 66.7 & 0 \\
\hline Captures information on staff profiles & 3 & 0 & 0 & 0 & 100 & 0 \\
\hline Enables easy accessing of employee's information when needed & 3 & 0 & 0 & 0 & 66.7 & 33.3 \\
\hline Generates reports for addressing HRM issues & 3 & 0 & 33.3 & 0 & 33.3 & 33.3 \\
\hline Enables HR departments to collect and assess employees' work information & 3 & 0 & 33.3 & 0 & 33.3 & 33.3 \\
\hline Supports payroll administration as well as pension and benefits management & 3 & 0 & 0 & 0 & 66.7 & 33.3 \\
\hline Enables monitoring of employees work attendance & 3 & 33.3 & 0 & 33.3 & 33.3 & 0 \\
\hline Enables employees to apply for leave online & 3 & 33.3 & 0 & 0 & 33.3 & 33.3 \\
\hline $\begin{array}{l}\text { Enables employees to query and receive HRM related information via SMSs on their } \\
\text { mobile phones }\end{array}$ & 3 & 33.3 & 0 & 0 & 33.3 & 33.3 \\
\hline
\end{tabular}

Source: Field data.

Table 5 shows that ICT integration in the participating universities HRM largely enhanced management of staff profiles (100\%), accessing employee's information (100\%) as well as payroll administration $(100 \%)$. These findings compare with those from lecturers on the same aspects as indicated on Table 1 where ICT integration is mostly shown to be influencing administrative functions of HRM. However, it is evident from the Table that the more 
sophisticated applications of ICT in HRM had not been fully embraced by public universities. Such applications include use of ICT in staff recruitment $(66.7 \%)$, generation of HRM reports $(66.6 \%)$, work information management (66.6\%), texting technology $(66.6 \%)$ and a very low rating of work attendance management (33.3\%). These results imply that public universities in Kenya have invested in ICT integration in HRM that largely promise efficient operations in employees' record management as well as payroll administration but minimally enhance strategic management of the HR. [15] argues that applications of human resource information systems (HRIS) in processes such as recruitment and selection, training and development, HR planning and performance appraisal are instrumental in supporting an organizations' long-term business goals. This is because employees are systematically sourced, developed and retained based on their values and performances in the organization. The lowly rated functions on public universities HRM could mean reliance on undependable manual systems which could in turn affect significant decisions due to dearth of accurate and timely HR information. This compromises performance of these institutions like in the case of Moi university that lost more than half a billion Kenyan shillings in form of salaries for otherwise redundant employees [16].

The administrators of the participating universities were further requested to indicate on a 5 point likert scale, their perceptions on items designed to measure the benefits of ICT integration in human resource management in their institutions. Their responses were as indicated on Table 6:

Table 6. Registrars' (Administration) Perceptions on Benefits of ICT Integration in HRM.

\begin{tabular}{|c|c|c|c|c|c|c|}
\hline \multirow{2}{*}{ Benefit } & \multicolumn{6}{|c|}{ Response (\%) } \\
\hline & $\mathbf{N}$ & SD & D & $\mathbf{U}$ & $\mathbf{A}$ & SA \\
\hline Improves efficiency of the human resource operations & 3 & 0 & 33.3 & 0 & 33.3 & 33.3 \\
\hline Improves quality and timeliness of HR services & 3 & 0 & 33.3 & 0 & 33.3 & 33.3 \\
\hline Improves quality of budgeting and payroll management & 3 & 0 & 0 & 0 & 66.7 & 33.3 \\
\hline Improves user experience due to availability of accurate, relevant and readily accessible information & 3 & 0 & 33.3 & 0 & 33.3 & 33.3 \\
\hline Reduces paper use by enabling applications to be submitted and handled digitally & 3 & 0 & 0 & 0 & 33.3 & 66.7 \\
\hline $\begin{array}{l}\text { Enhances better information sharing among sections involved with performance, productivity and welfare of } \\
\text { employees }\end{array}$ & 3 & 0 & 0 & 33.3 & 33.3 & 33.3 \\
\hline Ensures cost effectiveness due to reduction of office staff who lender services manually & 3 & 0 & 0 & 0 & 66.7 & 33.3 \\
\hline $\begin{array}{l}\text { Enhances smooth running of university by tracking and analyzing time keeping and work patterns of } \\
\text { workforce }\end{array}$ & 3 & 0 & 0 & 33.3 & 33.3 & 33.3 \\
\hline Enhances compliance with statutory obligations due to availability of accurate and timely data & 3 & 0 & 0 & 0 & 33.3 & 66.7 \\
\hline
\end{tabular}

Source: Field data.

Table 6 shows that ICT integration in public universities HRM was largely benefiting them through automation of processes such as budgeting and payroll management, digitization of employees' applications, reduction of office staff who lender services manually, and compliance with statutory obligations. All these functions were rated $100 \%$ based on Agree and Strongly Agree. These results imply that the universities were getting elementary benefits from the investments that they had put into the integration of ICT in their HRM services. However, benefits such as improved quality and timeliness of HR services (66.6\%), improved user experiences $(66.6 \%)$, informed performance management $(66.6 \%)$ as well as enhanced tracking and analysis of time keeping and work patterns of the workforce $(66.6 \%)$ were not fully realized. These results may be because of the inability of the ICT systems in place to leverage strategic human resource management in the participating universities. This is evidenced on Tables 1 and 5 respectively which indicated that ICT integration in these universities was mainly in the areas of employees' record management as well as payroll administration. It scantly supported technical and sophisticated HRM processes such as recruitment and selection, training and development as well as performance management.

[4] argue that a major justification for organizations to integrate ICT in HRM is the need to shift the role of HRM from transactions to SHRM. This is a more favourable approach to managing human resources that supports longterm business goals and outcomes with a strategic framework. Several studies show that there has been an increase in strategic application of ICT in HRM. [17] in a study on Sri Lankan industries showed that the most commonly used modules in HR department were training and development, recruitment and selection as well as performance appraisal. Another study on Indian companies also found that HR professionals had major applications of HRIS as recruitment and selection, compensation, performance appraisal, corporate communication as well as job analysis and design [18]. [19] on their part had predicted the most popular future applications of HRIS as training and development, career development, and performance appraisal/management. Here in Kenya, the Teachers' Service Commission (TSC) is making headway on integrating ICT in strategic human resource management processes such as recruitment, selection as well as performance appraisal management. The TSC has for instance introduced an online open performance appraisal system for teachers to strengthen supervision and to continuously monitor their performance in curriculum implementation at the institutional level. The appraisal system will be used to provide feedback, improve communication, and clarify roles and responsibilities [20]. The TSC online recruitment system also allows prospective job seekers to apply for advertised posts online. The applicants are provided with an online platform where they 
can upload copies of their academic certificates and other testimonials and they are also given an option of tracking their applications online. After the selection process, the successful applicants are invited for a face to face interview through the email addresses they provided during the application.

\section{Conclusion}

Integration of ICT has had a positive influence on HRM processes in public universities in Kenya. However, the integration is perceived to have more support on administrative functions such as employee's record management and payroll administration than on the strategic applications such as staff recruitment and selection, training and development as well as performance management. Consequently, most benefits noted are basic such as automation of processes like budgeting and payroll management, digitization of employees' information and compliance with statutory obligations due to availability of accurate and timely employees' data. Thus, benefits that would ensure the attainment of the institutions' long-term goals such as enhanced efficiency and effectiveness in recruitment and selection; training and development as well as in performance management processes are negligible. There is therefore need for higher focus on exploitation of ICT for strategic human resource management (SHRM) which is a more favourable approach to managing human resources that supports long-term institutional goals and outcomes with strategic framework.

\section{References}

[1] Acosta, F. R. (2004). Information Technology Strategic Plan of Olivarez College. Unpublished Doctoral Dissertation, University of Baguio, Philippines.

[2] Rawat, M. (2008). Application of Human Resource Information System (HRIS) In Higher Education-Holistic Approach. Trusting Islam, Knowledge and Professionalism in ECER Development Conference, 15-17.

[3] Ngai, E. W. \& Wat, F. K. (2006). Human Resource Information Systems. A Review and Empirical Analysis, 297314.

[4] Beckers, A. M. \& Bsat, M. Z. (2002). A DSS Classification Model for Research in Human Resource Management Information Systems, Journal of Information Systems Management, Vol. 19 No. 3, pp. 41-50.

[5] Republic of Kenya (2006). National ICT policy. Ministry of Information and Communication. Nairobi: Government printer
[6] Republic of Kenya (2005). Kenya education sector support programme. Nairobi: Government printer.

[7] Ndirangu, M. \& Kabira, J. G. (2012). The Role of ICT in Kenya's Higher Education. Techno LEARN: 2 (2): 221-238.

[8] Cochran, W. G. (1977). Sampling techniques (3rd ed.). New York: Wiley.

[9] Krejcie, R. V. \& Morgan, D. W. (1970). Determining sample size for research activities. Educational \& Psychological Measurement, 30, 607-610.

[10] Martinsons, M. (1994). Benchmarking Human Resource Information System in Canada and Hong Kong. Information and Management, 26 (6), 305-316.

[11] Young, N. (2009). Understanding the Research Process and Methods: An Introduction to Research Methods. Las Vegas: Acts Press.

[12] Ball, K. S. (2011). The use of Human Resource Information Systems: A survey. Personnel Review, 30 (5/6), 677-693.

[13] Gürol, Y., Wolff, A., \& Ertemsir, E. (2010). E-HRM in Turkey: A case study. Encyclopedia of E-Business Development and Management in the Global Economy.

[14] Midiwo, J (2015). Influence of human resource information systems on performance of Kenyan public universities. Unpublished Thesis.

[15] Marler, J. H. (2009). Making Human Resources Strategic by Going to the Net: Reality or Myth. The International Journal of Human Resource Management, 20 (3), 515-527.

[16] Ngila, D. (2016). Audit shows Shs. 1 billion lost at Moi varsity. Sunday Nation, October 2, 2016.

[17] De Alwis, A. C. (2010). The Impact of Electronic Human Resource Management on the Role of Human Resource Managers. $E+M$ Ekonomie A Management, 4, 47-60. http://www.ekonomie-

management.cz/download/1331826738 3ec7/04 alwis.pdf (June 10, 2012).

[18] Saharan, T., \& Jafri, S. (2012). Valuation of HRIS Status an Insight of Indian Companies' Perspectives. in Kundu, S. C., Punia, B. K., Narwal, K. P. and Singh, D. (Eds), Business Management: Key Research Issues, Excel Books, New Delhi, pp. 113-127.

[19] Teo, T. S. H., Soon, L. G.., \& Fedric, S. A. (2001). Adoption and Impact of Human Resource Information Systems (HRIS). Research and Practice in Human Resource Management, 9 (1), 101-117.

[20] Teachers Service Commission (TSC) (2016). Teachers Performance Appraisal and Development Tool. Nairobi: Government printer. 